\title{
Late holocene trends of phytoplankton productivity and anoxia as inferred from diatom and geochemical proxies in Lake Victoria, Eastern Africa
}

\section{Andama, J. B. Lejju, and C. U. Tolo}

Department of Biology, Faculty of Science, Mbarara University of Science and Technology, P.O. Box 1410, Mbarara, Uganda

Received: 24 August 2013 - Accepted: 10 October 2013 - Published: 12 November 2013 Correspondence to: M. Andama (andamamorgan@gmail.com)

Published by Copernicus Publications on behalf of the European Geosciences Union.
Late holocene trends of phytoplankton productivity and anoxia

M. Andama et al.

\section{Title Page}

14 $\rightarrow$

4

Back

Close

Full Screen / Esc

Printer-friendly Version

Interactive Discussion 


\section{Abstract}

Lake Victoria ecosystem has undergone major ecological changes in the recent decades. Sedimentary diatom analysis and $\mathrm{Fe} / \mathrm{Mn}$ determined by Energy Dispersive X-ray Fluorescence (EDXRF) have provided phytoplankton (diatom) productiv-

5 ity and the resultant anoxia $(\mathrm{Fe} / \mathrm{Mn})$ in Lake Victoria at Napoleon Gulf during the late Holocene (1778 calyrBP (calibrated years before present) to $2008 \mathrm{AD}$ ) with radiocarbon dates determined using Accelerator Mass Spectrometry standard method. The results showed that increased total diatom counts in Napoleon Gulf during the late Holocene correspond with increased $\mathrm{Fe} / \mathrm{Mn}$ ratio (anoxia) in some of the pro10 files and not in others and in most cases those that correspond correlate very well with increased eutrophication from nitrate input (Total Nitrogen, TN). Therefore slightly increased anoxia not related to increased diatom productivity was recorded in Lake Victoria at Napoleon Gulf from the period 1778 to 1135 calyrBP. There was slightly increased diatom productivity at Napoleon Gulf from the period 857 to $758 \mathrm{cal} \mathrm{yr}$ BP but it did not increase anoxia in the lake. The period 415 cal yrBP to 2008 AD recorded increased anoxia at Napoleon Gulf related to high diatom productivity especially from 415 to 390 cal yr BP and 191 cal yrBP to 2008 AD.

\section{Introduction}

Lake Victoria (surface area, $68800 \mathrm{~km}^{2}$ ) situated in East Africa is the second largest freshwater lake in the world and the largest in Africa (Crul, 1995). The lake basin (catchment area, $194300 \mathrm{~km}^{2}$ ) with an estimated population of 30 million people (UNEP, 2004) is densely populated recording a 3-4\% annual growth-rate (Bugenyi and Magumba, 1996). The ecosystem of the lake has undergone major changes during the past three decades, 1960s to 1990s (Bugenyi and Magumba, 1996); primary productivity of the lake appears to have risen to about 2 to 3-fold (Bugenyi and Magumba, 1996) and dominance in primary production has shifted from diatoms to blue green algae
BGD

10, 17663-17682, 2013

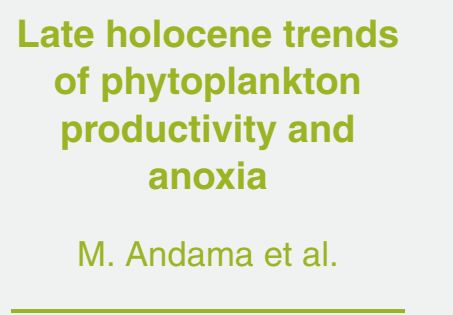

Title Page

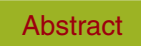

Introduction

Conclusions

Tables

References

Figures

14

4

Back

Close

Full Screen / Esc

Printer-friendly Version

Interactive Discussion
$>$ I

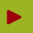

(Interactive Discussion

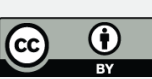


(Johnson, 1996). There have also been declines in hypolimnetic oxygen (anoxia below $40 \mathrm{~m}$ seasonally) (Bugenyi and Magumba, 1996) and bottom water anoxia of the lake has shifted from seasonal to permanent (Johnson, 1996) with $35-55 \%$ of the bottom area now enduring prolonged anoxia (Bugenyi and Magumba, 1996). The changes in oxygenation are consistent with measurements of higher algal biomass and productivity (Hecky et al., 1994). According to Lehman and Branstrator (1993), nitrogen (N) is the most limiting nutrient element for the phytoplanktons of Lake Victoria. However, there is limited information on the long term phytoplankton (diatom) productivity as a result of enrichment of the limiting nutrient element, nitrogen $(\mathrm{N})$ and the resultant anoxia in

Lake Victoria at Napoleon Gulf. The aim of this study is to establish the late Holocene phytoplankton (diatom) productivity as a result of enrichment of nitrogen $(\mathrm{N})$ and the resultant anoxia in Lake Victoria at Napoleon Gulf using Fe/Mn geochemical proxy.

\section{Materials and methods}

The $46 \mathrm{~cm}$ long LVNG2 sediment core was collected using Renberg corer from $11.3 \mathrm{~m}$ 15 depth (Fig. 1; $00^{\circ} 26^{\prime} 56.3^{\prime \prime} \mathrm{N}, 033^{\circ} 16^{\prime} 07.5^{\prime \prime} \mathrm{E}$, elevation, $1132 \mathrm{~m}$ ) in 2008 by the Millenium Science Initiative Project team members in Department of Biology, Mbarara University of Science and Technology and Department of Geology, Makerere University. The stratigraphy of the sediment core according to colour and texture and Total Nitrogen (TN) content were fully described in Andama et al. (2012).

\subsection{Radiocarbon dating}

The four accelerator mass spectrometer (AMS) ${ }^{14} \mathrm{C}$ dates for LVNG2 sediment core in Andama et al. (2012) determined using the standard method of Stuiver et al. (1998) were used. However the radiocarbon dates in Andama et al. (2012) had no age model, age correction term for reservoir effect and were not validated with other radiocarbon

dates obtained by previous researchers who did work in the same lake. A detailed age
$10,17663-17682,2013$

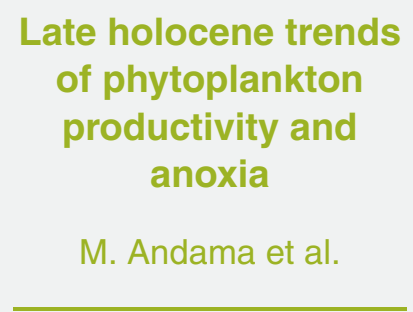

Title Page

Abstract

Introduction

Conclusions

Tables

References

Figures

14

4

Back

Close

Full Screen / Esc

Printer-friendly Version

Interactive Discussion $\rightarrow 1$
Intive Discussion 
model and chronology for LVNG2 sediment core is therefore described in this paper. Since bulk sediment materials were dated but not plant or animal remains, some of the conventional radiocarbon ages were subjected to $\sim 600 \mathrm{yr}$ radiocarbon correction for Lake Victoria sediments used by Stager and Johnson (2000), Stager et al. (1997) and 5 also recommended by Stuiver (1970). Comparisons of the radiocarbon ages with those obtained by previous researchers in Lake Victoria especially by Stager and Johnson (2000), Stager et al. (1997) and Kendall (1969) were also done to validate them. All the conventional ${ }^{14} \mathrm{C}$ dates were analysed with $2 \sigma$ errors and the suitable ages recalibrated using IntCal09 (Reimer et al., 2009).

10 An age model was produced for the sediments obtained from the coring site by the computer program OxCal v.4.1.7 (http://c14.arch.ox.ac.uk/oxcal.html) (Bronk Ramsey, 2009) used to construct a Poisson-process (P-sequence) deposition model for the sediment profile. Such models consider the sediment deposition as discrete events or increments, with a parameter $k$ as the number of increments per unit length and accommodate non-uniform deposition rates throughout the sequence (Bronk Ramsey, 2008). The P-sequence models for the core were run with varying values of $k$ until the highest $k$ of $16 \mathrm{~cm}^{-1}$ which gave a satisfactory agreement with the actual dating information (using the agreement indices) (Bronk Ramsey, 2008). The threshold for acceptable agreement index is $60 \%$ according to Bronk Ramsey (2008). In addition, LVNG2 sediment core mainly consisted of clay, silt and organic matter (Andama et al., 2012) but not coarse sand and a $\mathrm{k}$ value of 16 is accepted as according to Bronk Ramsey (2008), fine sediment might well have a value of $k$ up to $1000 \mathrm{~m}^{-1}\left(10 \mathrm{~cm}^{-1}\right)$ or possibly even higher. Age depth model for LVNG2 sediment core is shown in Fig. 2. Sediment accumulation rates were calculated by linear interpolation between the midpoints of consecutive pairs of ${ }^{14} \mathrm{C}$ date age ranges determined by the age models and were used for interpolating and extrapolating the calibrated ages.

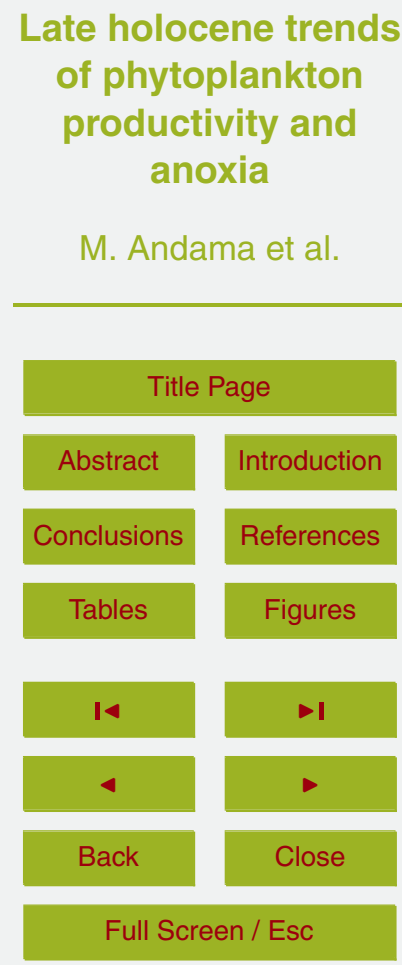




\subsection{Diatom analysis}

The diatom analysis involved the modification of the standard methods of Battarbee (1986) and Morley et al. (2004). Sediment subsamples were digested in $30 \% \mathrm{H}_{2} \mathrm{O}_{2}$, $40 \mathrm{~mL}$ of a $0.37 \mathrm{M} \mathrm{Na}$-citrate solution and $5 \mathrm{~mL}$ of a $1 \mathrm{M} \mathrm{NaHCO}_{3}$ solution were added

5 to remove iron oxide. To totally disaggregate the clays, a Calgon ${ }^{\circledR}$ treatment was performed by shaking the sediment sample in a $5 \%$ Sodium bicarbonate $\left(\mathrm{NaHCO}_{3}\right)$ solution for $30 \mathrm{~min}$ and carbonates were removed by adding $10 \% \mathrm{HCl}$. The samples were wet-sieved through nested 250-micron, 150-micron and 53-micron sieves to separate sand and larger particles from silt and clays. Clays of less than 5-microns were 10 removed by allowing silts to settle and supernatants decanted. The diatom fraction (supernatant) was centrifuged at $1500 \mathrm{rpm}$ for four minutes with distilled water. The supernatant containing the diatoms were then decanted using a pipette, dried on coverslips, and mounted on slides with DPX $(R I=1.525)$ for diatom analysis. All the diatoms on a slide were identified and counted. Diatom taxa were identified following 15 Hustedt (1949), Patrick and Reimer (1966), Van Der Werff and Huls (1976), Germain (1981), Hartley (1986), Gasse (1986), Kramer and Lange-Bertalot (1991) and Cumming et al. (1995). The total diatom counts were computed in the respective depths (Fig. 3) to ascertain productivity.

\subsection{Determination of Fe and Mn using Energy-Dispersive X-ray Fluorescence analyser}

Fe and Mn in LVNG2 sediment core were determined using the standard method, Energy- Dispersive X-ray Fluorescence (EDXRF) technique for non-destructive multielement analysis (Van Greiken and Markowicz, 1993) and Fe/Mn ratio computed. The $\mathrm{Fe} / \mathrm{Mn}$ ratio was then plotted besides the chronology as shown in Fig. 3. Changes 25 in $\mathrm{Fe} / \mathrm{Mn}$ ratio in the sediments are linked to changing redox conditions at the sediment surface (Koinig et al., 2003) and generally, increased bioproduction and increased anoxia in deeper waters lead to a stronger solution of $\mathrm{Mn}$ compared to Fe from the

Late holocene trends of phytoplankton productivity and anoxia

M. Andama et al.

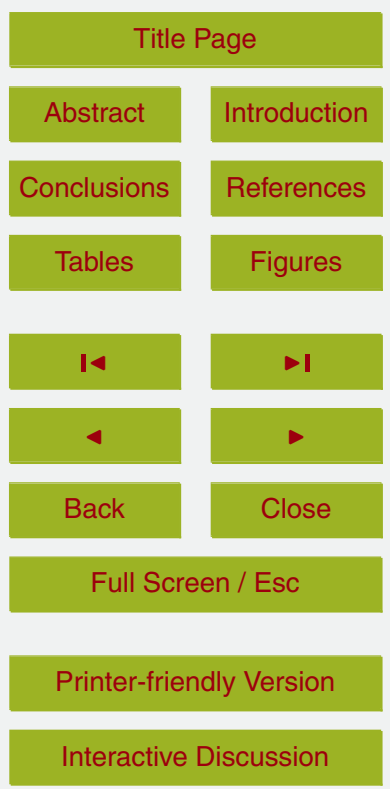


sediment, and thus to lower Mn concentration in the sediment hence high $\mathrm{Fe} / \mathrm{Mn}$ ratio (Koinig et al., 2003).

\section{Results}

\subsection{Chronology}

${ }_{5}$ The first $\mathrm{AMS}{ }^{14} \mathrm{C}$ date of $106.3 \pm 0.5$ at $11-12 \mathrm{~cm}$ depth did not require $600 \mathrm{yr}$ correction as it dated much younger. Neither did the $810 \pm 40$ radiocarbon age of LVNG2 core at $19-20 \mathrm{~cm}$ depth require $600 \mathrm{yr}$ correction as it is already consistent with the age at a similar depth of V95-2P sediment core (Stager and Johnson, 2000) from the same lake to which the $600 \mathrm{yr}$ ancient carbon reservoir adjustment was already applied. The 10 radiocarbon age of $3390 \pm 40$ at $44-45 \mathrm{~cm}$ depth might be spurious as it seemed to be very old for a sample as shallow as $44-45 \mathrm{~cm}$ depth thus the sample material at this depth was most probably re-worked/re-deposited hence excluded from the chronology. This exclusion decision is supported by two factors; firstly, the age $3390 \pm 40$ is only comparable with the age $3510 \pm 60$ at a much higher depth of $217 \mathrm{~cm}$ of V9515 2P sediment core (Stager and Johnson, 2000). Secondly the age of $3390 \pm 40$ at $44-$ $45 \mathrm{~cm}$ depth was inconsistent with the other dates in the $P_{\text {sequence }}$ model as it gave low agreement, below the threshold for acceptable agreement index of $60 \%$ (e.g. Blockley et al., 2008; Bronk Ramsey, 2008). The uncorrected and corrected radiocarbon ages for LVNG2 sediment core are shown in Table 1.

20 The midpoints of consecutive pairs of ${ }^{14} \mathrm{C}$ date age ranges obtained from the age models (Fig. 2) were the actual ages in calyrBP of the sediment core. These midpoints i.e. $1777.5 \mathrm{cal}$ yrBP $(46 \mathrm{~cm}), 1195$ cal yrBP $(33.5 \mathrm{~cm}), 638.5 \mathrm{cal}$ yrBP $(19.5)$ and $241 \mathrm{calyr} B \mathrm{P}(11.5 \mathrm{~cm})$ were used to calculate the sediment accumulation rates. The sedimentation rates were therefore $0.021 \mathrm{~cm} \mathrm{yr}^{-1}$ between 46 to $33.5 \mathrm{~cm}$ depth, $0.025 \mathrm{~cm} \mathrm{yr}^{-1}$ from 33.5 to $19.5 \mathrm{~cm}$ and $0.020 \mathrm{~cm} \mathrm{yr}^{-1}$ from 19.5 to $11.5 \mathrm{~cm}$. Each of the sedimentation rates was used to interpolate the calyrBP between the respective
BGD

$10,17663-17682,2013$
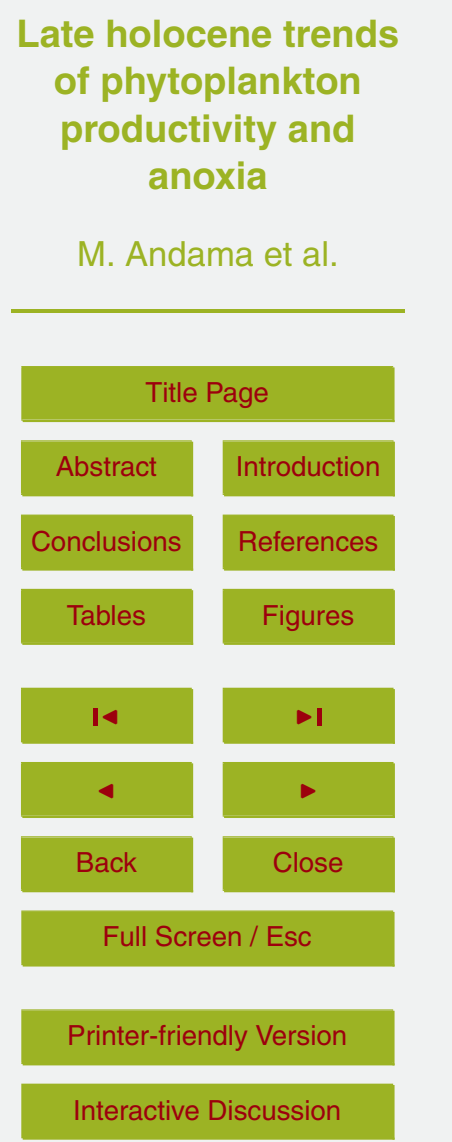
depths and the $0.020 \mathrm{~cm} \mathrm{yr}^{-1}$ sedimentation rate between 19.5 to $11.5 \mathrm{~cm}$ depth was used to extrapolate the 0 calyrBP i.e., $1950 \mathrm{AD}$ due to lack of access to ${ }^{210} \mathrm{~Pb}$ dating facility hence 0 cal yrBP was reached at a depth of $6.65 \mathrm{~cm}$ which also marked the end of ${ }^{14} \mathrm{C}$ date extrapolation. The entire chronology of LVNG2 core based on only ${ }^{14} \mathrm{C}$ 5 dates was obtained and plotted with total diatom counts and geochemical proxies as shown in Fig. 3.

\subsection{Diatom counts and Fe/Mn ratio in LVNG2}

The different genera of diatoms identified included Aulacoseira, Stephanodiscus, Nitzschia, Fragilaria, Achnanthes, Amphora, Epithemia, Navicula, Cocconeis and Cym10 bella. Total diatom accounts at the different depths of LVNG2 sediment core were got and $\mathrm{Fe} / \mathrm{Mn}$ ratios obtained. The diatom record and $\mathrm{Fe} / \mathrm{Mn}$ ratios were divided qualitatively into the following four sedimentary intervals (Fig. 3) for convenience of interpretation.

Zone LVNG2 A (46-32 cm): in this zone dating from 1778 to 1135 cal yrBP, diatoms 15 were absent from depths 46-39 cm (1778-1451 cal yr BP) and recorded very low numbers of 3,2 and 12 at $38.5 \mathrm{~cm}$ (1428 calyrBP), $36.5 \mathrm{~cm}$ (1335 calyr BP) and $32.5 \mathrm{~cm}$ (1155 calyrBP) depths respectively. Slightly elevated $\mathrm{Fe} / \mathrm{Mn}$ ratios (109.83-173.43) were recorded in this zone decreasing towards the top of the zone.

Zone LVNG2 B $(32-22.5 \mathrm{~cm})$ : this zone dating from 1135 to $758 \mathrm{calyrBP}$ had few diatoms towards the bottom with only 22 total counts recorded at $30.5 \mathrm{~cm}$ depth (1076 calyrBP). Depths between 30.5 and $24.5 \mathrm{~cm}$ (1076 to $837 \mathrm{calyrBP}$ ) did not record any diatom counts. However, diatom counts slightly increased towards the top of this zone with 169 counts recorded at $24.5 \mathrm{~cm}$ depth (837 calyr BP) followed by a decrease to 47 counts at $22.5 \mathrm{~cm}$ depth ( $758 \mathrm{cal}$ yrBP). Slightly low Fe/Mn ratios (100.00-

Zone LVNG2 C $(22.5-15 \mathrm{~cm})$ : this zone dating between 758 and $415 \mathrm{calyrBP}$ recorded a very scarce number of diatoms with only 14 and 43 total counts registered

BGD

10, 17663-17682, 2013

Late holocene trends of phytoplankton productivity and

anoxia

M. Andama et al.

Title Page

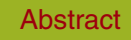

Introduction

Conclusions

Tables

References

Figures

14

4

Back

Full Screen / Esc

Printer-friendly Version

Interactive Discussion $\rightarrow$

Close 
at $19.5 \mathrm{~cm}$ (639 cal yrBP) and $16.5 \mathrm{~cm}$ (489 cal yr BP) depths respectively while the rest of the depths did not have diatoms. Fe/Mn ratios were relatively high (120.00-185.22) in this zone dating between 758 and 415 calyrBP and increased towards the top of the zone.

$5 \quad$ Zone LVNG2 D $(15-0 \mathrm{~cm})$ : in this zone dating from 415 calyrBP to $2008 \mathrm{AD}$, there was generally an increase in total diatom counts with most of the values ranging between 43 to 893 counts particularly from depths $15-14.5 \mathrm{~cm}$ and $10.5-0 \mathrm{~cm}$. However, depths between 14.5 and $10.5 \mathrm{~cm}$ (390 to $191 \mathrm{calyr} B \mathrm{P}$ ) recorded very low diatom counts. The lowest diatom count of 25 was only recorded at $12.5 \mathrm{~cm}$ 10 depth (291 calyrBP) while the highest count of 893 was recorded at $8.5 \mathrm{~cm}$ depth (92 calyrBP). Diatom counts rapidly decreased from 893 counts at $8.5 \mathrm{~cm}$ depth (92 calyrBP) to 58 counts at $4.5 \mathrm{~cm}$ depth followed by a slight increase to 80 counts at $2.5 \mathrm{~cm}$ depth and finally a gentle decrease to 59 counts at $0.5 \mathrm{~cm}$ depth (towards 2008 $\mathrm{AD})$. This zone dating from 415 cal yrBP to $2008 \mathrm{AD}$ generally had very high $\mathrm{Fe} / \mathrm{Mn}$ 15 ratios (145.08-241.32) punctuated with some abrupt fluctuations with $\mathrm{Fe} / \mathrm{Mn}$ ratios increasing towards the top of the zone.

\section{Discussion}

\subsection{Phytoplankton (diatom) productivity and anoxia at Napoleon Gulf}

The trend of phytoplankton (diatom) productivity and anoxia at Napoleon Gulf was qualitatively divided into the following four time periods for convenience of discussion.

\subsubsection{8 to 1135 cal yr BP}

The scarcity of diatom counts during this period signified low diatom productivity. This should be due to insufficiency of limiting nutrient element, nitrogen $(N)$ as total nitrogen recorded low values from 46-32 cm depths (Andama et al., 2012) which now date 1778 to 1135 calyr BP. The relatively elevated $\mathrm{Fe} / \mathrm{Mn}$ ratio during this period should have 17670
$10,17663-17682,2013$
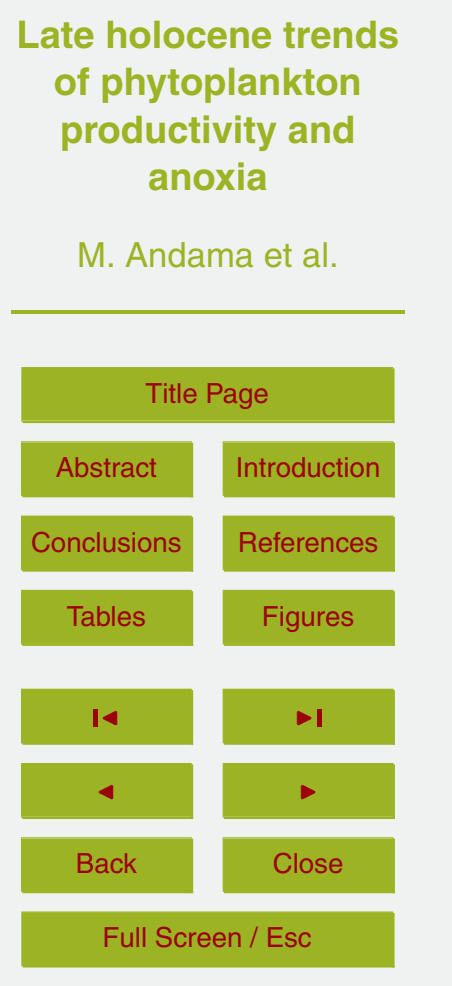

Printer-friendly Version

Interactive Discussion 
been possibly due to other causes but not increased diatom productivity. Johnson et al. (2000) argued that some 9800 to $7500 \mathrm{yr}$ ago, from purely natural causes, limnological conditions in Lake Victoria deteriorated to a state comparable to that of today. This implies that natural causes also had great influence on the limnology of Lake Victoria 5 in the past.

\subsubsection{5 to 758 cal yr BP}

Diatom counts generally indicated relatively reduced productivity during the period 1135 to 857 calyrBP followed by a slight increase in productivity from 857 to 758 calyrBP. The diatom productivity patterns seemed to agree well with the pattern of the limiting nutrient element, nitrogen $(\mathrm{N})$ using total nitrogen. This is in agreement with the findings of Lehman and Branstrator (1993) who found that nitrogen (N) is the most limiting nutrient element for the phytoplanktons of Lake Victoria. On overall, diatom productivity in the period 1135 to 758 cal yrBP was relatively higher than that from 1778 to 1135 calyrBP. Total nitrogen also showed slightly increased values from 32 to $22.5 \mathrm{~cm}$ depths (Andama et al., 2012) which now date 1135 to $758 \mathrm{calyrBP}$ and relatively low values from 46 to $32 \mathrm{~cm}$ (Andama et al., 2012) dating 1778 to $1135 \mathrm{cal}$ yrBP. However the Fe/Mn ratio was generally lower during the period 1135 to 758 cal yrBP than the previous period dating from 1778 to 1135 calyrBP signifying that the diatom productivity did not increase anoxia to high levels.

\subsubsection{8 to 415 cal yr BP}

Low diatom productivity was also registered throughout this period and it seemed to agree very well with reduced total nitrogen only from $22.5-18.5 \mathrm{~cm}$ depth (Andama et al., 2012) dating 758-589 cal yrBP. The low diatom counts in the period dating from 589 to 415 calyrBP amidst increasing total nitrogen from 18.5 to $15 \mathrm{~cm}$ depths (Andama et al., 2012) dating 589 to 415 calyrBP possibly meant that there were other dominant phytoplanktons in Lake Victoria during that period but not diatoms. According

Late holocene trends of phytoplankton productivity and anoxia

M. Andama et al.

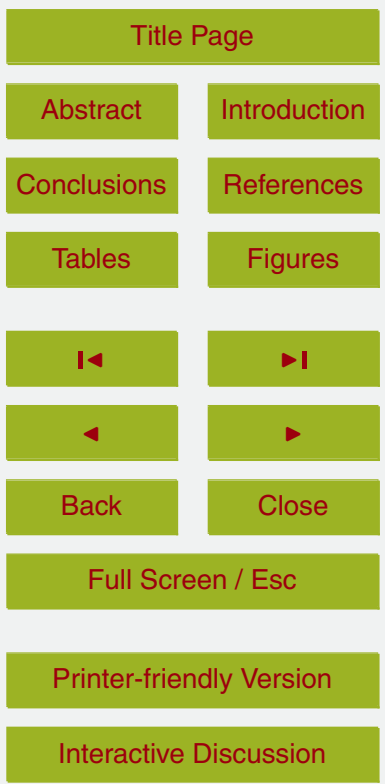


to Thomasson (1955), phytoplanktons of Lake Victoria include diatoms, blue-greens, desmids, chlorococcalean and other green algae and dinoflagellate. The generally increasing pattern of $\mathrm{Fe} / \mathrm{Mn}$ during the period 758 to 415 cal yrBP probably signified increasing anoxia from other causes but not increased diatom productivity as previously 5 stated.

\subsubsection{5 cal yr BP to 2008 AD}

The generally increased diatom counts during the periods 415 to 390 calyrBP and 191 calyrBP to 2008 AD though decreasing towards 2008 AD signified high diatom productivity during those periods. This was due to sufficient limiting nutrient element, ni10 trogen $(\mathrm{N})$ in the lake as according to Andama et al. (2012), total nitrogen recorded very high values from 15 to $0 \mathrm{~cm}$ depths dating 415 cal yr BP to 2008 AD. Stager et al. (2009) found out that the changes in diatoms in Lake Victoria more likely reflect responses to long-term nutrient enrichment and climatic instability in the region. The very low diatom counts recorded from the period 390 to $191 \mathrm{calyrBP}$ and the decreasing pattern of diatom counts after 1950 AD towards 2008 AD possibly signified decreased diatom productivity during the period 390 to 191 cal yrBP and decreasing trend of productivity after 1950 AD towards 2008 AD. This implies that primary productivity in Lake Victoria should have been dominated by other phytoplanktons during the period 390 to 191 calyrBP and those periods after 1950 AD towards 2008 AD other than diatoms. in primary production of Lake Victoria has shifted from diatoms to blue green algae during the past three decades, 1960s to 1990s. Sitoki et al. (2010) also found out that algal species composition in Lake Victoria has changed from dominance of diatoms to toxic nitrogen fixing cyanobacteria along with an increase in algal biomass, which resulted

The generally high $\mathrm{Fe} / \mathrm{Mn}$ ratio during the period 415 calyrBP to $2008 \mathrm{AD}$ possibly signified increased anoxia from high diatom productivity especially from 415 to 390 calyrBP and 191 calyrBP to 2008 AD. This is partly in agreement with the find-

BGD

10, 17663-17682, 2013

Late holocene trends of phytoplankton productivity and anoxia

M. Andama et al.

Title Page

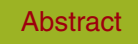

Introduction

Conclusions

Tables

References

Figures

14

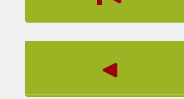

Back

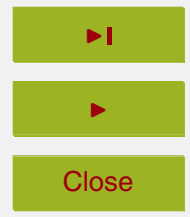

Full Screen / Esc

Printer-friendly Version

Interactive Discussion 
ings of Lipiatou et al. (1996) who found out that anoxic conditions have existed in Lake Victoria for the last $200 \mathrm{yr}$. According to the study, the last episode of increased anoxia in the lake occurred from the period 190 calyrBP to 2008 AD. Ostenfeld (1908) and Worthington (1930) found out that anoxic, "putrifying" bottom sediments occurred both 5 inshore and offshore of Lake Victoria as early as 1904-1905 and 1927-1928, leading Worthington (1930) to classify the lake as eutrophic. In addition, global climatic change has affected thermal stratification of lake Victoria (Hecky et al., 1994) and thermal stratification enhances chemical reactions favouring the accumulation of toxic organic compounds and anoxic conditions (Njiru et al., 2011). Increases in temperature affect the levels of dissolved oxygen in the water column, which is inversely proportional to temperature (Hauer and Hill, 1996). Lake Victoria is now warmer and thermal stratification more stable which increases the occurrence of hypoxia (Hecky et al., 1994; Sitoki et al., 2010). On average, the surface waters of Lake Victoria have warmed by almost $1.2^{\circ} \mathrm{C}$ in $82 \mathrm{yr}$ since 1927 while the temperature rose by $1.57^{\circ} \mathrm{C}$ in water $>50 \mathrm{~m}$ deep over the same time period (Sitoki et al., 2010). According to Mackay (2007), higher Lake Victoria levels were positively associated with increased sunspot numbers in the last $200 \mathrm{yr}$. Therefore, there was a possibility of warming of the lake leading to thermal stratification and anoxic conditions in the bottom waters in the last $200 \mathrm{yr}$. Mugidde et al. (2005) obtained low dissolved oxygen levels at the bottom during stratification in Lake Victoria at Napoleon Gulf, Uganda, an inshore shallow station compared to surface dissolved oxygen levels during periods of thermal stability of the lake. The increased intensity of deoxygenation during the stratified period, when $>50 \%$ of the water column was said to become anoxic (Fish, 1956; Schofield and Chapman, 2000). The increased anoxia during the period 390 to 191 calyrBP can be attributed to other causes but not increased diatom productivity.

BGD

$10,17663-17682,2013$

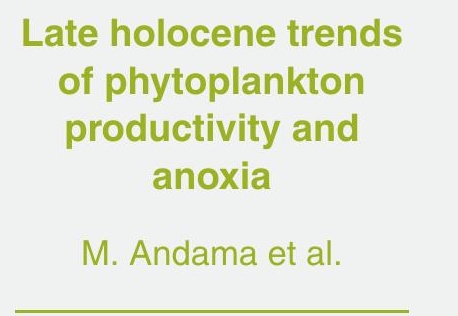

Title Page

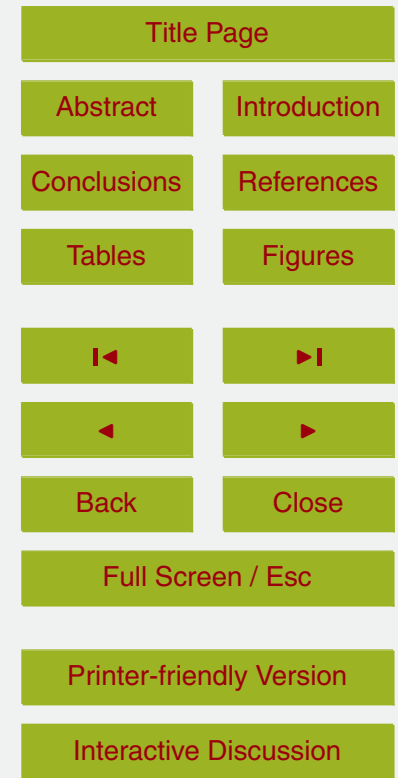




\section{Conclusions}

- Increased total diatom counts in Napoleon Gulf during the late Holocene correspond with increased $\mathrm{Fe} / \mathrm{Mn}$ ratio (anoxia) in some of the profiles and not in others and in most cases those that correspond correlate very well with increased eutrophication from nitrate input (Total Nitrogen, TN).

- Slightly increased anoxia not related to increased diatom productivity was recorded in Lake Victoria at Napoleon Gulf from the period 1778 to 1135 cal yrBP.

- Lake Victoria experienced slightly increased diatom productivity at Napoleon Gulf from the period 857 to 758 calyr BP but it did not increase anoxia in the lake.

- The period 415 calyrBP to 2008 AD recorded increased anoxia in Lake Victoria at Napoleon Gulf related to high diatom productivity especially from 415 to 390 cal yr BP and 191 calyr BP to 2008 AD.

Acknowledgements. Thanks to Julius Bunny Lejju (Project Supervisor) and Casim Umba Tolo. I am greatly indebted to the Government of Uganda and Uganda National Council for Science and Technology (UNCST) for the financial support through the Millennium Science Initiative (MSI) Research grants.

\section{References}

Andama, M., Lejju, B. J., Tolo, C. U., Kagoro-Rugunda, G., Ssemmanda, I., and Ayebare, J.: Late holocene environmental history of Lake Victoria Basin: evidence from geochemical proxies, J. Environ. Sci. Eng. B, 1, 1054-1063, 2012.

Batterbee, R. W.: Diatom analysis, in: Handbook of Holocene Palaeoecology and Palaeohydrology, edited by: Berglund, B. E., John Wiley and Sons Ltd., Toronto, 527-528, 1986.

Blockley, S. P. E., Ramsey, C. B., Lane, C. S., and Lotter, A. F.: Improved age-modelling approaches as exemplified by the revised chronology for the central European varved lake
BGD

10, 17663-17682, 2013

Late holocene trends

of phytoplankton

productivity and

anoxia

M. Andama et al.

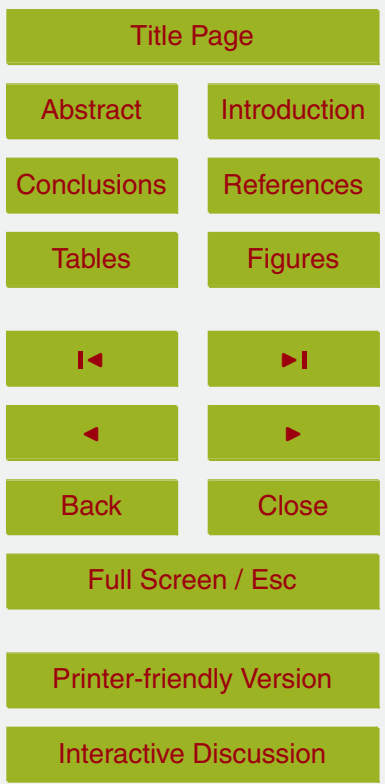


Bronk Ramsey, C.: Deposition models for chronological records, Quaternary Sci. Rev., 27, 4260, 2008.

Bronk Ramsey, C.: Bayesian analysis of radiocarbon dates, Radiocarbon, 51, 337-360, 2009.

Bugenyi, F. W. B. and Magumba, K. M.: The present physicochemical ecology of Lake Victoria,

5 Uganda, in: The Limnology, Climatology and Paleoclimatology of the East African Lakes, edited by: Odada, E. O. and Johnson, T. C., Gordon and Breach, the Netherlands, 141-154, 1996.

Crul, R. C. M.: Limnology and hydrology of Lake Victoria, Ver. Inter. Ver. Limno., 25, 39-48, 1995.

10 Cumming, B. F., Wilson, S. E., Hall, R. I., and Smol, J. P.: Bibliotheca Diatomologica Band 31: Diatoms from British Columbia (Canada) Lakes and their Relationship to Salinity, Nutrients and Other Limnological Variables, J. Cramer, Berlin, 1995.

Fish, G. R.: Some aspects of the respiration of sex species of fish from Uganda, J. Exp. Biol., 33, 186-195, 1956.

15 Gasse, F.: East African Diatoms: Taxonomy, Ecological Distribution, Bibl. Diatomol., Band 11, J. Cramer, Stuttgart, 1986.

Germain, H.: Flore des Diatomees, Diatomophycees: Eaux Douces et Saumatres du Massif Armoricain et des Contrees Voisines d'Europe Occidentale, Société Nouvelle des Editions Boubee, Paris, 1981.

20 Hartley, B.: A checklist of the freshwater, brackish and marine diatoms of the British Isles and adjoining coastal waters, J. Mar. Biol. Assoc. UK, 66, 531-610, 1986.

Hauer, F. R. and Hill, W. R.: Temperature, light, and oxygen, in: Methods in Stream Ecology, edited by: Hauer, F. R. and Lamberti, G. A., Academic Press, San Diego, 1996.

Hecky, R. E., Bugenyi, F. W. B., Ochumba, P., Talling, J. F., Mugidde, R., Gophen, M., and Kaufman, L.: Deoxygenation of the deep water of Lake Victoria, East Africa, Limnol. Oceanogr., 39, 1476-1481, 1994.

Hustedt, F.: Süsswasser Diatomeen aus dem Albert-National Park und Belgische- Kongo. Expl. du Parc Nat. Albert, Miss. H. Damas (1935-1936), 8, 1-199, 1949.

Johnson, T. C.: Sedimentary processes and signals of past climate change in the Large Lakes of the East African Rift Valley, in: The Limnology, Climatology and Paleoclimatology of the East African Lakes, edited by: Odada, E. O. and Johnson, T. C., Gordon and Breach, the Netherlands, 367-412, 1996.

Late holocene trends of phytoplankton productivity and

anoxia

M. Andama et al.

Title Page

Abstract

Conclusions

Tables

14

4

Back

Full Screen / Esc

Printer-friendly Version

Interactive Discussion 
Johnson, T. C., Kelts, K., and Odada, E. O.: The Holocene history of Lake Victoria, Ambio, 29, 2-11, 2000.

Kendall, R. L.: An ecological history of the Lake Victoria basin, Ecol. Monogr., 39, 121-176, 1969.

5 Koinig, K. A., Shortyk, W., Lotter, A. F., Ohlendorf, C., and Sturm, M.: 9,000 years of geochemical evolution of lithogenic major and trace elements in the sediment of an alpine lake - the role of climate, vegetation, and landuse history, J. Paleolimnol., 30, 307-320, 2003.

Kramer, K. and Lange-Bertalot, H.: Suesswasserflora von Mitteleuropa, 3. Teil: Centrales, Fragilariaceae, Eunotiaceae, Fischer Verlag, Stuttgart, 1991.

10 Lehman, J. T. and Brandstrator, D. K.: Effects of nutrients and grazing on phytoplankton of Lake Victoria, Verh. Internat. Verein. Limnol., 25, 850-855, 1993.

Lipiatou, E., Hecky, R. E., Eisenreich, S. J., Lockhart, L., Muir, D., and Wilkinson, P.: Recent ecosystem changes in Lake Victoria reflected in sedimentary natural and anthropogenic organic compounds, in: The Limnology, Climatology and Paleoclimatology of the East African Lakes, edited by: Odada, E. O. and Johnson, T. C., Gordon and Breach, the Netherlands, 523-541, 1996.

Mackay, A. W.: Large Lakes, Elsevier B.V. publishers, 2007.

Morley, D. W., Leng, M. J., Mackay, A. W., Sloane, H. J., Rioual, P., and Battarbee, R. W.: Cleaning of lake sediment samples for diatom oxygen isotope analysis, J. Paleolimnol., 31, $20 \quad 391-401,2004$.

Mugidde, R., Gichuki, J., Rutagemwa, D., Ndawula, L., and Matovu, A.: Status of water quality and its implication on fishery production, in: The state of the fisheries resources of Lake Victoria and their management, Poceedings of the regional stakeholders' conference, Entebbe, Uganda- LVFO, Jinja, Uganda, 106-112, ISBN 9970-713-10-12, 2005.

Njiru, M., Nyamweya, C., Gichuki, J., Mugidde, R., Mkumbo, O., and Witte, F.: Increase in anoxia in Lake Victoria and its effects on the fishery, in: Anoxia, edited by: Padilla, P., Intech, Open Access Publisher, 99-128, ISBN 979-953-307-139-7, available at: www.Intechweb.org, 2011.

Ostenfeld, C. H.: Phytoplankton aus dem Victoria Nyanza, Sammelausbeute von A. Bogert, 1904-1905, Botanisches Jahrbuch, 41, 330-350, 1908.

Patrick, R. and Reimer, C. W.: The diatoms of the United States, Vol. 1, Monogr. Acad. Nat. Sci., Philadelphia, 1966.

Late holocene trends of phytoplankton productivity and

anoxia

M. Andama et al.

Title Page

Abstract

Conclusions

Tables

14

4

Back

Full Screen / Esc

Printer-friendly Version

Interactive Discussion 
Reimer, P., Baillie, M. G. L., Bard, E., Bayliss, A., Beck, J. W., Blackwell, P. G., Bronk Ramsey, C., Buck, C. E., Burr, G. S., Edwards, R. L., Friedrich, M., Grootes, P. M., Guilderson, T. P., Hajdas, I., Heaton, T. J., Hogg, A. G., Hughen, K. A., Kaiser, K. F., Kromer, B., McCormac, F. G., Manning, S. W., Reimer, R. W., Richards, D. A., Southon, J. R., Talamo, S., Turney, C. S. M., van der Plicht, J., and Weyhenmeyer, C. E.: IntCal09 and Marine09 radiocarbon age calibration curves, 0-50,000 years cal BP, Radiocarbon, 51, 1111-1150, 2009.

Schofield, P. J. and Chapman, L. J.: Hypoxia tolerance of introduced Nile perch: implications for survival of indigenous fishes in the Lake Victoria Basin, Afr. Zool., 35, 35-42, 2000.

Sitoki, L., Gichuki, J., Ezekiel, C., Wanda, F., Mkumbo, O. C., and Marshall, B. E.: The environment of Lake Victoria (East Africa): current status and historical changes, Int. Rev. Hydrobiol., 95, 3, 209-223, 2010.

Stager, J. C. and Johnson, T. C.: A 12,400 14C yr offshore diatom record from east central Lake Victoria, East Africa, J. Paleolimnol., 23, 373-383, 2000.

Stager, J. C., Cumming, B., and Meeker, L. D.: An 11,400-year, high-resolution diatom record from Lake Victoria, East Africa, Quaternary Res., 47, 81-89, 1997.

Stager, J. C., Hecky, R. E., Grzesik, D., Cumming, B. F., and Kling, H.: Diatom evidence for the timing and causes of eutrophication in Lake Victoria, East Africa, Hydrobiologia, 636, 463478, 2009.

Stuiver, M.: Long-term C14 variations, in: Radiocarbon Variations and Absolute Chronology, Proc. 12th Nobel Symp., Uppsala, edited by: Olsson, I. U., John Wiley and Sons, New York, 197-213, 1970.

Stuiver, M., Reimer, P. J., Bard, R. E., Beck, J. W., Burr, G. S., Hughen, K. A., Kromer, B., McCormac, G., van der Plicht, J., and Spurk, M.: INTCAL98 Radiocarbon age calibration, 24,000-0 cal BP, Radiocarbon, 40, 1041-1083, 1998.

Thomasson, K.: A plankton sample from Lake Victoria, Svensk botanica Tkidskdsr, 49, 22592274, 1955.

UNEP, Odada, E. O., Olago, D., Kulindwa, K. A. A., Bugenyi, F., West, K., Ntiba, M., Wandiga, S., and Karimumuryango, J.: East African Rift Valley Lakes, GIWA Regional assessment 47, University of Kalmar, Kalmar, Sweden, 2004.

30 Van Der Werff, A. and Huls, H.: Diatomeeenflora Van Nederland (Diatom Flora of the Netherlands), Otto Koeltz Science Publications, West Germany, 1976.

Van Greiken, R. E. and Markowicz, A. A.: Handbook of X-ray Spectrometry, 14 edn., Marcel Dekker, Inc., New York, 1993.
BGD

10, 17663-17682, 2013

Late holocene trends

of phytoplankton

productivity and

anoxia

M. Andama et al.

Title Page

Abstract

Introduction

Conclusions

Tables

References

Figures

14

4

Back

Close

Full Screen / Esc

Printer-friendly Version

Interactive Discussion 
Worthington, E. B.: Observations on the temperature, hydrogen-ion concentration, and other physical conditions of the Victoria and Albert Nyanzas, Int. Rev. Ges. Hydrobio., 25, 328357, 1930.

Late holocene trends of phytoplankton productivity and anoxia

M. Andama et al.

Title Page

Abstract

Conclusions

Tables

14

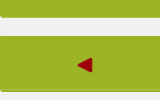

Back

Introduction

References

Figures

\section{Full Screen / Esc}

Printer-friendly Version

Interactive Discussion 
Table 1. Accelerator mass spectrometer (AMS) radiocarbon dates from LVNG2 core. Asterisk designates samples that required no $600 \mathrm{yr}$ correction.

\begin{tabular}{lllll}
\hline $\begin{array}{l}\text { Sample depth } \\
\text { Range }(\mathrm{cm})\end{array}$ & $\begin{array}{l}\text { Sample } \\
\text { depth }(\mathrm{cm})\end{array}$ & $\begin{array}{l}\text { Lab ID Number } \\
\#{ }^{14} \mathrm{C} \text { age }\end{array}$ & $\begin{array}{l}\text { Uncorrected } \\
{ }^{14} \mathrm{C} \text { age }\end{array}$ & $\begin{array}{l}\text { Corrected } \\
{ }^{14} \mathrm{C}\end{array}$ \\
\hline $11-12$ & 11.5 & Beta-276809 & $106.3 \pm 0.5$ & $106.3^{*} \pm 0.5$ \\
$19-20$ & 19.5 & Beta-278725 & $810 \pm 40$ & $810^{*} \pm 40$ \\
$33-34$ & 33.5 & Beta-276810 & $1830 \pm 40$ & $1230 \pm 40$ \\
$44-45$ & 44.5 & Beta-276811 & $3990 \pm 40$ & $3390 \pm 40$ \\
\hline
\end{tabular}

Late holocene trends of phytoplankton productivity and anoxia

M. Andama et al.

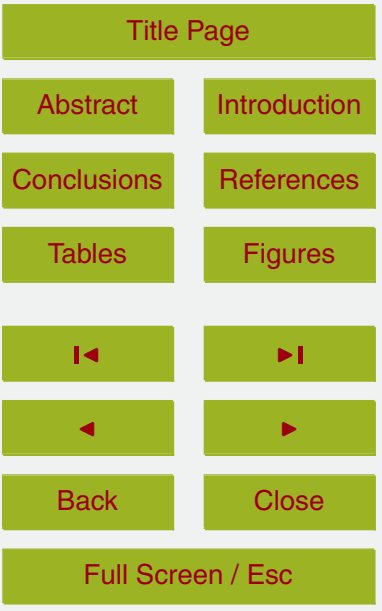

Printer-friendly Version

Interactive Discussion 


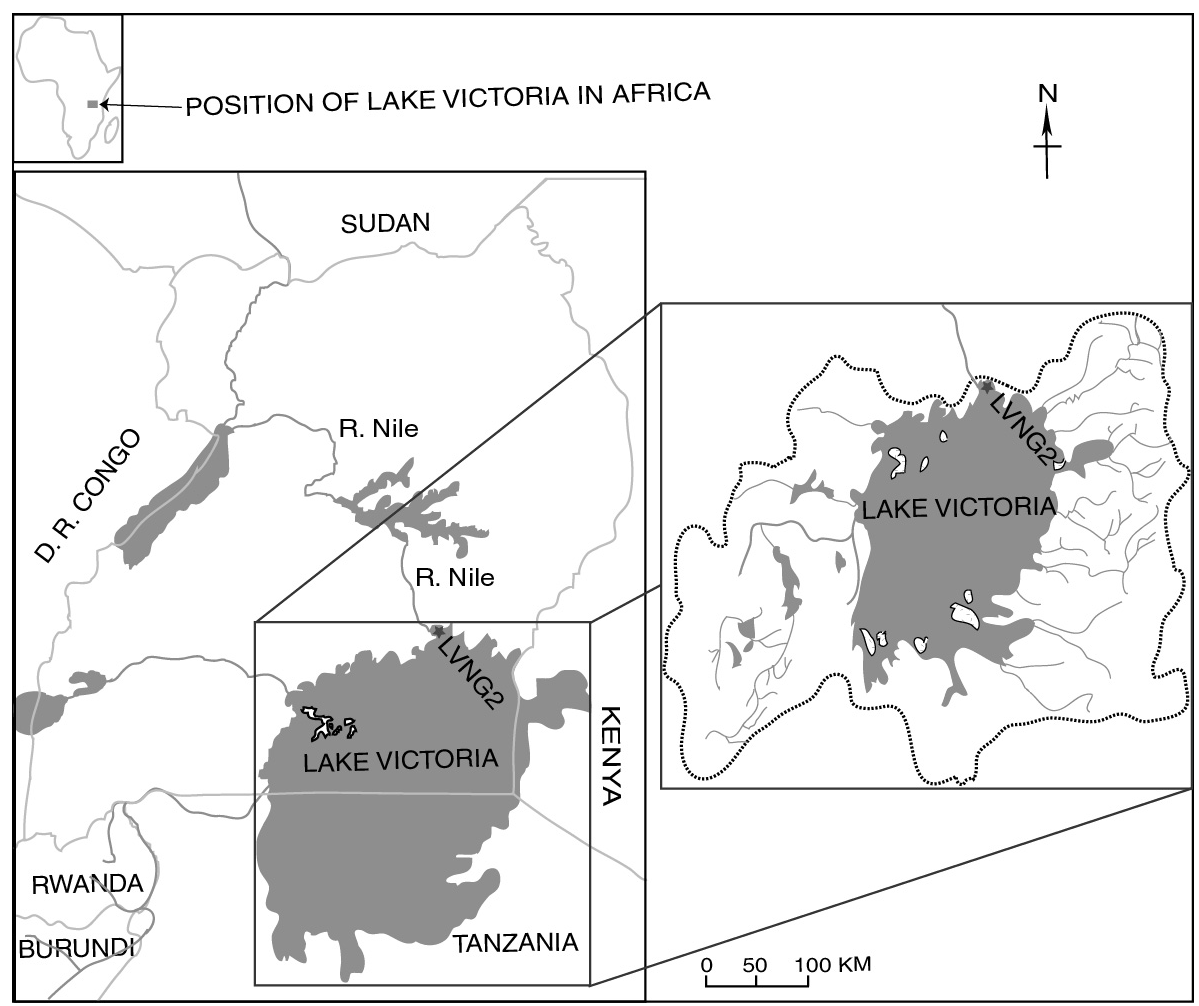

BGD

10, 17663-17682, 2013

Late holocene trends of phytoplankton productivity and anoxia

M. Andama et al.

Title Page

Abstract

Introduction

Conclusions

References

Tables

Figures

14

- I

4

Back

Close

Full Screen / Esc

Fig. 1. Map of Uganda showing Lake Victoria and Lake Victoria Napoleon Gulf 2 (LVNG2).

Printer-friendly Version

Interactive Discussion 


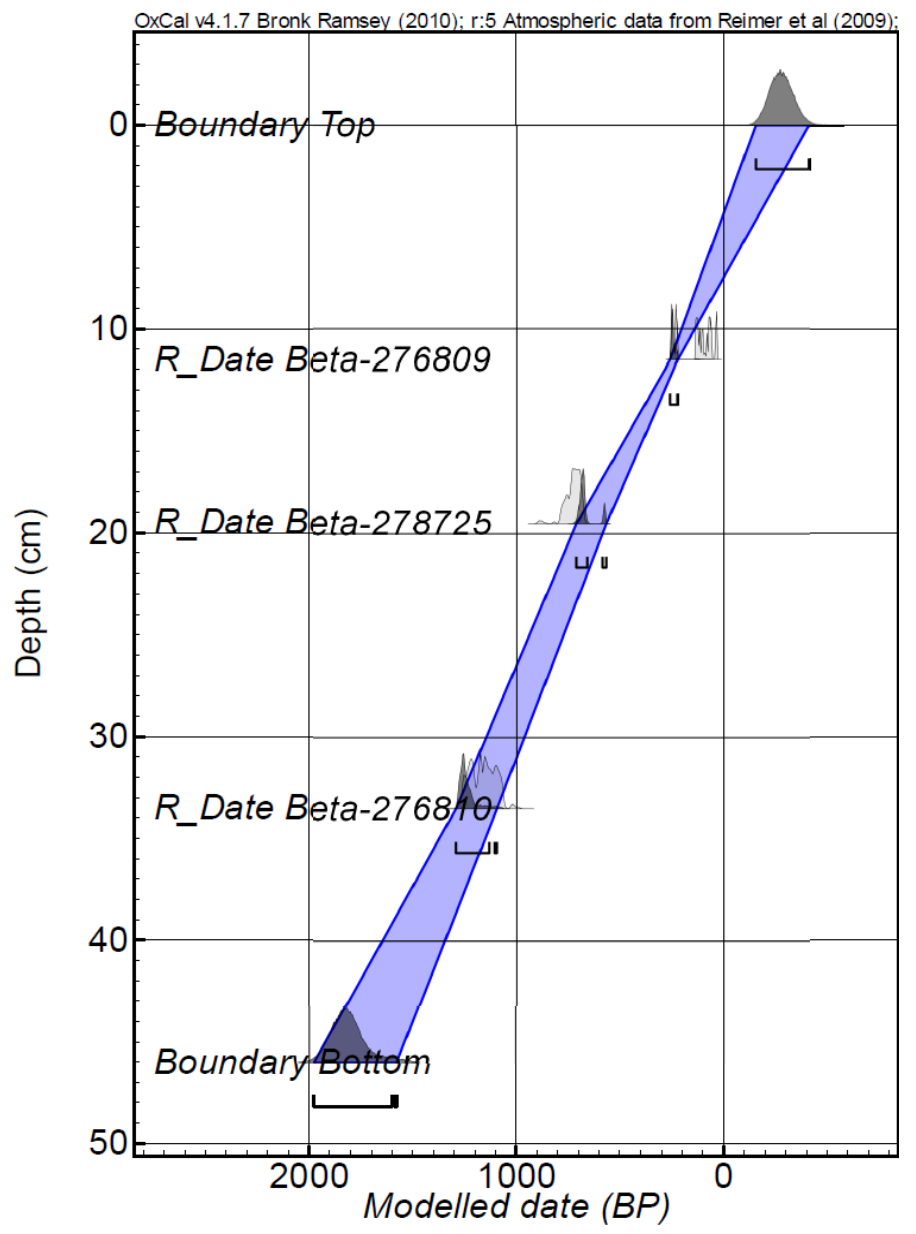

BGD

10, 17663-17682, 2013

Late holocene trends of phytoplankton productivity and anoxia

M. Andama et al.

Title Page

Abstract

Conclusions

Tables

14

4

Back

Full Screen / Esc

Printer-friendly Version

Interactive Discussion the deposition is a Poisson process $\left(P_{\text {sequence }}\right), k=16$. 


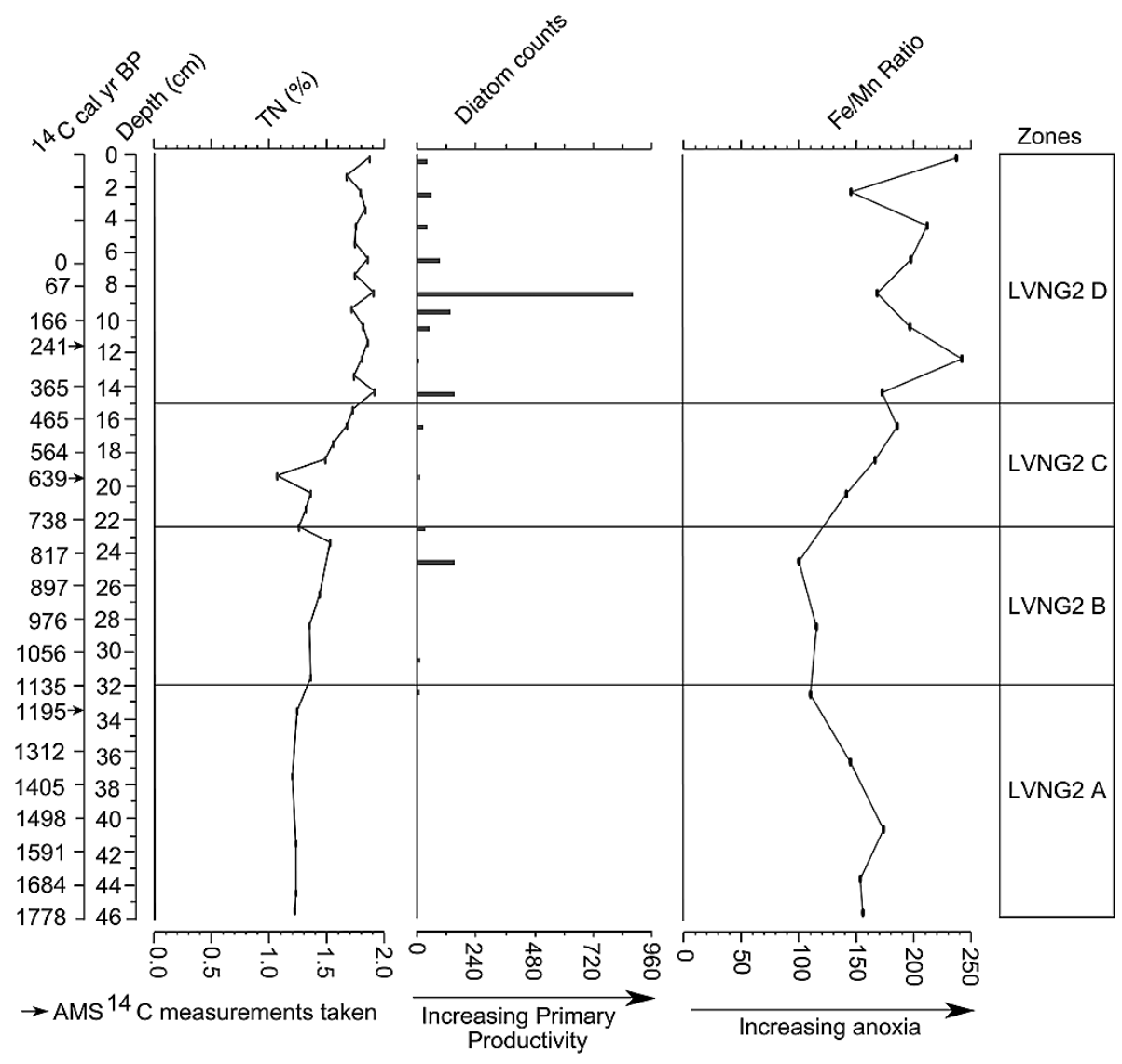

Fig. 3. Total Nitrogen (TN) (Andama et al., 2012), diatom counts and Fe/Mn composition of bulk sediment of LVNG2 core.
BGD

10, 17663-17682, 2013

Late holocene trends of phytoplankton productivity and anoxia

M. Andama et al.

Title Page

Abstract

Introduction

Conclusions

References

Tables

Figures

14

4

Back

Close

Full Screen / Esc

Printer-friendly Version

Interactive Discussion 